\title{
Hypothalamic Response to Kisspeptin-54 and Pituitary Response to Gonadotropin-Releasing Hormone Are Preserved in Healthy Older Men
}

\author{
Ali Abbara ${ }^{a}$ Shakunthala Narayanaswamy ${ }^{a}$ Chioma Izzi-Engbeaya ${ }^{a}$ \\ Alexander N. Comninos ${ }^{a}$ Sophie A. Clarke ${ }^{a}$ Zainab Malik ${ }^{a}$ \\ Deborah Papadopoulou $^{a} \quad$ Ailish Clobentz $^{\mathrm{a}}$ Zubair Sarang $^{\mathrm{a}}$ Paul Bassett $^{\mathrm{b}}$ \\ Channa N. Jayasena ${ }^{a}$ Waljit S. Dhillo ${ }^{a}$ \\ a Section of Endocrinology and Investigative Medicine, Imperial College London, Hammersmith Hospital, \\ London, UK; b Statsconsultancy Ltd., Amersham, UK
}

\section{Keywords}

Kisspeptin-54 - Testosterone · Ageing · Gonadotropins · Gonadotropin-releasing hormone $\cdot$ Hypothalamus .

Pituitary

\begin{abstract}
Background: Male testosterone levels decline by $1 \%$ per year from the age of 40 years. Whilst a primary testicular deficit occurs, hypothalamic or pituitary dysregulation may also coexist. This study aimed to compare the hypothalamic response to kisspeptin-54 and the pituitary response to gonadotropin-releasing hormone (GnRH) of older men with those of young men. Methods: Following $1 \mathrm{~h}$ of baseline sampling, healthy older men $(n=5$, mean age $59.3 \pm 2.9$ years) received a 3-h intravenous infusion of either vehicle, kisspeptin-54 $0.1,0.3$, or $1.0 \mathrm{nmol} / \mathrm{kg} / \mathrm{h}$ or $\mathrm{GnRH} 0.1 \mathrm{nmol} /$ $\mathrm{kg} / \mathrm{h}$, on five different study days. Serum gonadotropins and total testosterone were measured every $10 \mathrm{~min}$ and compared to those of young men ( $n=5 /$ group) (mean age 28.9 \pm 2.0 years) with a similar body mass index $\left(24 \mathrm{~kg} / \mathrm{m}^{2}\right)$ who
\end{abstract}

underwent the same protocol. Results: Kisspeptin-54 and $\mathrm{GnRH}$ significantly stimulated serum gonadotropin release in older men compared to vehicle ( $p<0.001$ for all groups). Gonadotropin response to kisspeptin-54 was at least preserved in older men when compared to young men. At the highest dose of kisspeptin-54 $(1.0 \mathrm{nmol} / \mathrm{kg} / \mathrm{h})$, a significantly greater luteinising hormone $(\mathrm{LH})(p=0.003)$ response was observed in older men. The follicle-stimulating hormone (FSH) response to $\mathrm{GnRH}$ was increased in older men ( $p=$ $0.002)$, but the LH response was similar $(p=0.38)$. Serum testosterone rises following all doses of kisspeptin-54 $(p \leq$ 0.009 ) were reduced in older men. Conclusions: Our data suggest that healthy older men without late-onset hypogonadism (LOH) have preserved hypothalamic response to kisspeptin-54 and pituitary response to $\mathrm{GnRH}$, but impaired testicular response. Further work is required to investigate the use of kisspeptin-54 to identify hypothalamic deficits in men with $\mathrm{LOH}$.

(C) 2018 The Author(s)

Published by S. Karger AG, Basel

\section{A. Abbara and S. Narayanaswamy are joint first authors.}

\begin{tabular}{|c|c|}
\hline KARGER & $\begin{array}{l}\text { () } 2018 \text { The Author(s) } \\
\text { Published by S. Karger AG, Basel }\end{array}$ \\
\hline $\begin{array}{l}\text { E-Mail karger@karger.com } \\
\text { www.karger.com/nen }\end{array}$ & $\begin{array}{l}\text { This article is licensed under the Creative Commons Attribution } 4.0 \\
\text { International License (CC BY) (http://www.karger.com/Services } \\
\text { OpenAccessLicense). Usage, derivative works and distribution are } \\
\text { permitted provided that proper credit is given to the author and the } \\
\text { original publisher. }\end{array}$ \\
\hline
\end{tabular}

Prof. Waljit S. Dhillo

Section of Endocrinology and Investigative Medicine, Imperial College London 6th Floor, Commonwealth Building, Hammersmith Hospital, Du Cane Road London W12 ONN (UK)

E-Mail w.dhillo@imperial.ac.uk 


\section{Introduction}

Ageing is commonly associated with a decline in sex steroid production, with an estimated $20 \%$ of men in their $60 \mathrm{~s}$, and $50 \%$ of men in their 80 s having total testosterone levels below the reference range $(<11.3 \mathrm{nmol} / \mathrm{L})$ [1]. Whilst some men remain asymptomatic despite biochemical hypogonadism, others develop symptoms such as muscle weakness, loss of bone mass, cognitive decline, sexual dysfunction, reduced libido, and erectile dysfunction [2]. The existence of symptoms in combination with evidence of biochemical hypogonadism due to advancing age is termed late-onset hypogonadism ( $\mathrm{LOH})$.

Serum gonadotropin levels are used to distinguish primary hypogonadism (raised follicle-stimulating hormone $[\mathrm{FSH}] /$ luteinising hormone $[\mathrm{LH}]$ due to testicular dysfunction) from secondary hypogonadism (low FSH/LH due to hypothalamopituitary disorders). In the European Male Ageing Study, 9\% of hypogonadism was labelled as primary hypogonadism, $50 \%$ as secondary hypogonadism, and $41 \%$ as "compensated hypogonadism," whereby an increased LH level (>9.4 U/L) was required to maintain serum testosterone above $10.5 \mathrm{nmol} / \mathrm{L}$ [3].

Some studies have contested whether total testosterone does fall with increasing age. In a recent cross-sectional study of 2,908 men in China, there was no decrease in total testosterone with age, although sex hormone-binding globulin (SHBG) and serum LH both increased with age, suggesting a degree of compensation for testicular insensitivity and the possibility of a decline in free testosterone levels [4]. Similarly, Kelsey et al. [5] did not find any evidence of a further reduction in total testosterone beyond the age of 40 years, although there was increased variability in total testosterone at older ages.

Previous studies have suggested that the fall in testosterone with age is due to a primary testicular defect, with an impairment of Leydig cell function [6]. Older men had a lower rise in serum testosterone following human chorionic gonadotropin (hCG) or LH administration when compared to younger men [7-9]. This is consistent with data from rodent studies suggesting reduced testicular sensitivity to $\mathrm{LH}$ in older rats and a defect in the LH-cyclic adenosine monophosphate signalling cascade [10].

However, it is less clear whether there is also a hypothalamic or pituitary defect with ageing. As testosterone declines with age, there is a subsequent rise in gonadotropins consistent with reduced testicular sensitivity.
However, the rise in gonadotropins is not as great as that seen in younger men with hypogonadism, suggesting an additional hypothalamic-pituitary defect $[10,11]$. Secretion of $\mathrm{LH}$ is also more disordered in older men $[3,12]$ and LH per burst is reduced [13-16], despite baseline LH secretion being increased $[17,18]$. In the European Male Ageing study, obesity was the greatest determinant of the variance in total testosterone with age [2]. Importantly, the relationship between the fall in testosterone with age and obesity may be bidirectional, with a low testosterone also predisposing to an increase in body mass index (BMI) [2]. Thus, $\mathrm{LOH}$ is a complex condition that is often due to combined dysfunction at multiple levels of the hypothalamic-pituitary-gonadal (HPG) axis. It is therefore important to develop novel strategies to identify the site of defect in the HPG axis in LOH.

Currently, only pituitary function can be directly evaluated using gonadotropin-releasing hormone (GnRH) [19]. Gonadotropin response to GnRH is similar in older and younger men, suggesting that the pituitary remains responsive to GnRH [15-18]. However, it has not previously been possible to directly evaluate the HPG axis at the hypothalamic level. Studies in aged rats demonstrated reduced hypothalamic $\mathrm{GnRH}$ release compared to young rats $[9,10,20-23]$. There is a paucity of data in humans investigating whether hypothalamic GnRH release is impaired in older men. This is predominantly because of the impracticalities of directly sampling blood from the hypothalamopituitary portal vessels to measure GnRH release in humans, with only indirect assessment of hypothalamic $\mathrm{GnRH}$ function being possible. Graded inhibition of hypothalamic function with a GnRH receptor antagonist has suggested that ageing reduces hypothalamic GnRH secretion to cause relative hypogonadotropic hypogonadism in older men [24]. However, a reliable hormonal secretagogue that directly stimulates $\mathrm{GnRH}$ release in humans has not previously been evaluated. Kisspeptin is a recently identified regulator of puberty and reproduction that activates the HPG axis by inducing GnRH secretion from the hypothalamus [25-27]. Kisspeptin administration to men has been shown to potently stimulate reproductive hormone release [28]. Hence, kisspeptin has the potential to directly probe endogenous $\mathrm{GnRH}$ reserve in humans.

Based on the data above, we hypothesised that older men could have reduced hypothalamic GnRH reserve compared to young men. To test this hypothesis, we investigated whether the hypothalamic response to kisspeptin-54 and the pituitary response to $\mathrm{GnRH}$ are preserved in healthy older men. 
Table 1. Baseline characteristics of young and older men

\begin{tabular}{|c|c|c|c|c|c|c|c|c|}
\hline Participant No. & Age, years & Weight, kg & BMI & LH, IU/L & FSH, IU/L & $\begin{array}{l}\text { Testosterone, } \\
\text { nmol/L }\end{array}$ & $\begin{array}{l}\mathrm{SHBG}, \\
\mathrm{nmol} / \mathrm{L}\end{array}$ & FAI \\
\hline \multicolumn{9}{|c|}{ Older participants } \\
\hline 1 & 66 & 79.5 & 25.1 & 5.02 & 6.79 & 23.62 & 53.4 & 46.9 \\
\hline 2 & 58 & 78.2 & 24.0 & 2.51 & 4.34 & 15.71 & 42.5 & 41.0 \\
\hline 3 & 66 & 90.0 & 26.3 & 4.81 & 2.68 & 13.02 & 34.4 & 31.1 \\
\hline 4 & 55 & 86.0 & 24.3 & 4.69 & 3.03 & 14.84 & 43.3 & 33.2 \\
\hline Mean & 59.3 & 79.7 & 24.0 & 3.75 & 3.74 & 15.78 & 38.5 & 42.5 \\
\hline SEM & 2.9 & 4.3 & 1.0 & 0.68 & 0.86 & 2.07 & 5.7 & 5.3 \\
\hline \multicolumn{9}{|c|}{ Young participants } \\
\hline 1 & 25 & 75.9 & 26.5 & 4.40 & 2.21 & 18.78 & 21.9 & 85.75 \\
\hline 2 & 23 & 82.7 & 24.1 & 4.69 & 2.67 & 31.40 & 33.2 & 94.58 \\
\hline 7 & 30 & 68.7 & 25.2 & 3.10 & 2.09 & 13.65 & 13.9 & 98.20 \\
\hline 8 & 30 & 62.2 & 20.2 & 1.78 & 1.66 & 29.75 & 28.1 & 105.87 \\
\hline 9 & 26 & 71.3 & 23.4 & 2.61 & 2.84 & 17.05 & 25.3 & 67.39 \\
\hline 10 & 30 & 83.9 & 23.7 & 5.30 & 1.74 & 20.52 & 30.5 & 67.28 \\
\hline Mean & 28.9 & 74.10 & 23.61 & 3.52 & 2.50 & 20.60 & 26.66 & 77.27 \\
\hline SEM & 2.02 & 2.69 & 0.68 & 0.43 & 0.25 & 2.03 & 2.33 & 87.12 \\
\hline
\end{tabular}

Younger participant data reproduced from Jayasena et al. [29] by permission of Oxford University Press/Human Reproduction and adapted from Table 1 in the same paper available under the terms of the CC BY licence. BMI, body mass index; FAI, free androgen index (calculated as total testosterone divided by SHBG level $\times 100$ ); FSH, follicle-stimulating hormone; LH, luteinising hormone; SHBG, sex hormone-binding globulin.

\section{Materials and Methods}

\section{Participants}

Healthy male volunteers aged $>50$ years were recruited through newspaper advertisements. They underwent a detailed medical evaluation as part of the pre-study screening to assess their suitability. The screening visit involved obtaining informed consent, medical history, medication history, clinical examination, electrocardiogram, and the following blood tests: full blood count, renal profile, liver profile, bone profile, random glucose, thyroid profile, prolactin, LH, FSH, testosterone, and SHBG. Participants fulfilling the following criteria were recruited: no known medical problems or allergies, no medication use, no recreational drug use, no previous research study participation, and no blood donation within the preceding 3 months. Clinical examination, electrocardiogram, and blood tests were all normal. Five participants were recruited into the study. The details of their age, weight, BMI, and baseline serum gonadotropins and testosterone are presented in Table 1.

Study 1: Determining the Effects of Kisspeptin-54 and GnRH on Gonadotropin Release in Older Men

This was a single-blinded study with the subjects being unaware of the intervention received. Participants attended the clin- ical research facility for five study visits, at least 1 week apart, and received a different intervention at each visit. Study visits all took place during the morning and lasted for $4 \mathrm{~h}$ in total. A summary of the study protocol for each visit is shown in Figure 1.

Subjects were asked to refrain from strenuous exercise, sexual activity, and alcohol consumption for the 24 -h period preceding each study visit. On arrival in the morning, participants were cannulated in both forearms and asked to lie supine. After $1 \mathrm{~h}$ of baseline blood sampling, an intravenous infusion of vehicle - kisspeptin-54 or GnRH - was commenced and continued for $3 \mathrm{~h}$. During three of the five study visits, kisspeptin-54 was administered at each of the following doses previously shown to induce robust rises in serum LH [29]: $0.1,0.3$, or $1.0 \mathrm{nmol} / \mathrm{kg} / \mathrm{h}$. GnRH was administered at $0.1 \mathrm{nmol} / \mathrm{kg} / \mathrm{h}$, which has also previously been shown to significantly stimulate gonadotropin release [29]. Additionally, this allowed us to compare the effects of $\mathrm{GnRH}$ versus kisspeptin-54 at the same equimolar dose $(0.1 \mathrm{nmol} / \mathrm{kg} / \mathrm{h})$. Blood samples were taken at 10-min intervals throughout the 4-h study period to measure reproductive hormones. Blood samples were collected in plain serum vacutainer tubes and allowed to clot prior to centrifugation and separation of the serum. The samples were centrifuged at 3,000 rpm for $10 \mathrm{~min}$, separated, and then frozen at $-20^{\circ} \mathrm{C}$ until analysis. 
Fig. 1. Protocol diagram for study visits. Blood sampling was done every $10 \mathrm{~min}$ for serum LH and FSH for $240 \mathrm{~min}$. After $1 \mathrm{~h}$ of baseline blood sampling, infusions of kisspeptin-54, GnRH, or vehicle were commenced. The initial infusion rate was doubled for the first $30 \mathrm{~min}$ to achieve steadystate levels more rapidly. Maintenance infusion rates were $0.1,0.3$, and $1.0 \mathrm{nmol} /$ $\mathrm{kg} / \mathrm{h}$ of each peptide. Each participant received the same dose of each peptide (kisspeptin-54 or GnRH) in random order at least 1 week apart ( $n=5$ per dose). FSH, follicle-stimulating hormone; GnRH, gonadotropin-releasing hormone; LH, luteinising hormone.

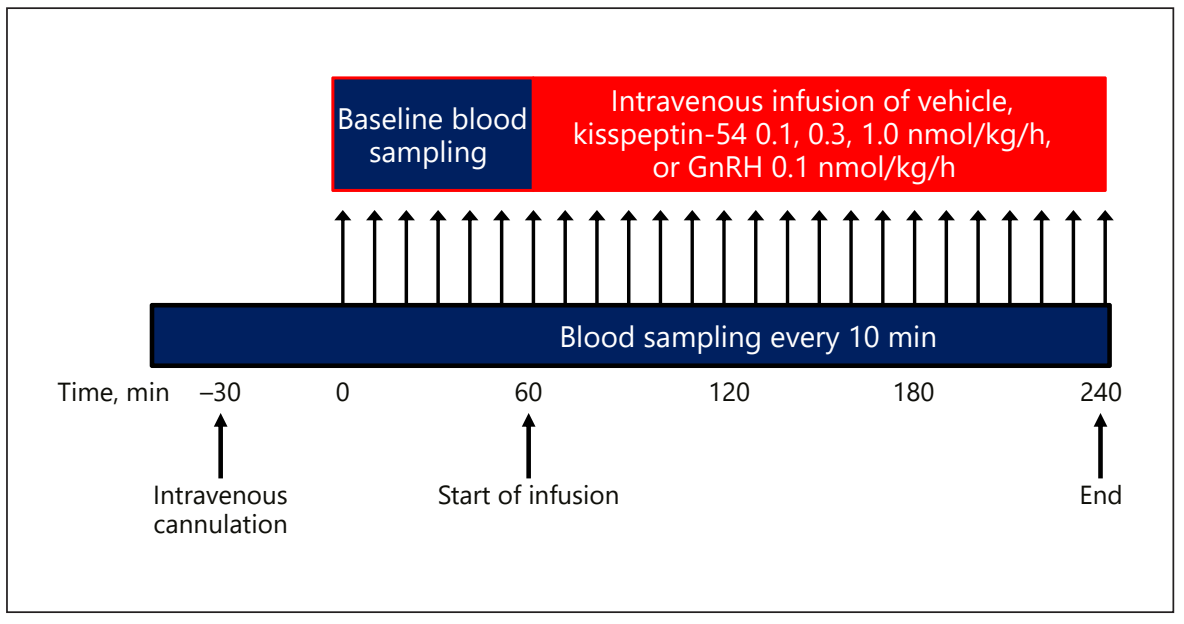

The infusion rates were doubled in the first $30 \mathrm{~min}$ to rapidly achieve steady-state plasma levels during the infusion period [30]. Therefore, total doses of $0.35,1.05$, or $3.5 \mathrm{nmol} / \mathrm{kg}$ kisspeptin-54 peptide were administered during the 3 -h infusions, with maintenance administration rates of $0.1,0.3$, or $1.0 \mathrm{nmol} / \mathrm{kg} / \mathrm{h}$, respectively. The total dose of $\mathrm{GnRH}$ administered was $0.35 \mathrm{nmol} /$ $\mathrm{kg}$ over the 3-h infusion, with a maintenance infusion rate of $0.1 \mathrm{nmol} / \mathrm{kg} / \mathrm{h}$. Participants had their blood pressure and pulse recorded on arrival and at regular intervals throughout the study.

\section{Study 2: Comparison of the Gonadotropin Response to}

Kisspeptin-54 and GnRH in Older and Young Men

We have previously published the effects of vehicle, kisspeptin-54 (0.1, 0.3, and $1.0 \mathrm{nmol} / \mathrm{kg} / \mathrm{h})$ and $\mathrm{GnRH}(0.1 \mathrm{nmol} /$ $\mathrm{kg} / \mathrm{h}$ ), infusion in young men [29]. In order to compare the gonadotropin response to kisspeptin-54 and GnRH in older men to that in young men, we used data from study 1 of this paper and our previously published data from young men [29]. All study visits and hormonal analyses for both the young and the older group were undertaken between January 2013 to February 2014 using the same batches of $\mathrm{GnRH}$ and kisspeptin-54.

\section{Peptide}

Human kisspeptin-54 was synthesised by Advanced Biotechnology Centre (Imperial College London, London, UK) and further purified and tested as previously described [28] consistent with the standards for physiological research studies. Vials of freeze-dried kisspeptin- 54 were stored at $-20^{\circ} \mathrm{C}$ and then reconstituted with $0.9 \%$ saline. The rate of infusion was calculated based on body weight. A fixed volume of the peptide solution from the reconstituted vial was transferred into a $50-\mathrm{mL}$ syringe containing Gelofusine (5\% vol/vol) (B. Braun Medical, Sheffield, UK), which was used as the vehicle to minimise peptide absorption to the administration apparatus [31].

Gonadorelin $100 \mu \mathrm{g}(\mathrm{GnRH})$ was purchased from Intrapharm laboratories Ltd. (Maidenhead, UK). It was reconstituted with the supplied sterile solvent, which contained $2 \%$ benzyl alcohol and water for injection. A fixed volume of peptide solution was then transferred into a 50-mL syringe containing Gelofusine and infused at a rate determined by the weight-based calculation.

\section{Hormonal Analysis}

Frozen samples were defrosted and analysed for measurement of $\mathrm{LH}, \mathrm{FSH}$, and testosterone using automated chemiluminescent immunoassays (Abbott Diagnostics, Maidenhead, UK) within 6 months of the clinical studies being carried out. Reference ranges were as follows: LH 4.0-14.0 IU/L, FSH 1.5-8.0 IU/L, and testosterone $10.0-28.0 \mathrm{nmol} / \mathrm{L}$. The respective intra- and interassay coefficients of variation for each assay were 4.1 and $2.7 \%$ (LH), 4.1 and $3.0 \%(\mathrm{FSH})$, and 4.2 and $2.8 \%$ (total testosterone). Analytical sensitivities were $0.5 \mathrm{IU} / \mathrm{L}(\mathrm{LH}), 0.05 \mathrm{IU} / \mathrm{L}(\mathrm{FSH})$, and $2 \mathrm{nmol} / \mathrm{L}$ (total testosterone).

\section{Statistical Analysis}

Study 1: Determining the Effects of Kisspeptin-54 and GnRH on Gonadotropin Release in Older Men. Statistical analysis of the data was performed by the study statistician (P.B.). Analyses were performed by modelling the response over time for each study group. To allow for variations in the baseline outcome values, the analysis considered the change in each parameter from the baseline value. The baseline hormonal values were considered to be an average of the first $30 \mathrm{~min}$ prior to starting the infusion of peptide or vehicle (average of hormonal levels from 30 to $60 \mathrm{~min}$ ). To allow for the repeat measurements over time, the analysis was performed using multilevel linear regression. Two-level models were used with individual measurements nested within patients. Treatment group was considered to be a fixed effect. To allow a flexible curved relationship between time and the outcome variable, linear, squared, and cubic terms for time were included if found to improve the fit. Due to the relatively large number of combinations between pairs of groups, only comparisons with a $p$ value $<0.01$ were considered statistically significant. As both kisspeptin-54 and GnRH were administered at $0.1 \mathrm{nmol} / \mathrm{kg} / \mathrm{h}$, these two groups were also compared directly in order to evaluate the hypothalamic response to kisspeptin-54 administration and the pituitary response to $\mathrm{GnRH}$ at equimolar doses of kisspeptin-54 and GnRH, respectively.

Study 2: Comparison of the Gonadotropin Response to Kisspeptin-54 and GnRH in Older and Young Men. Similar to study 1, the analyses were performed by modelling the hormonal response over time, with the added comparison between age and treatment group. To allow for the repeat measurements over time, the analy- 


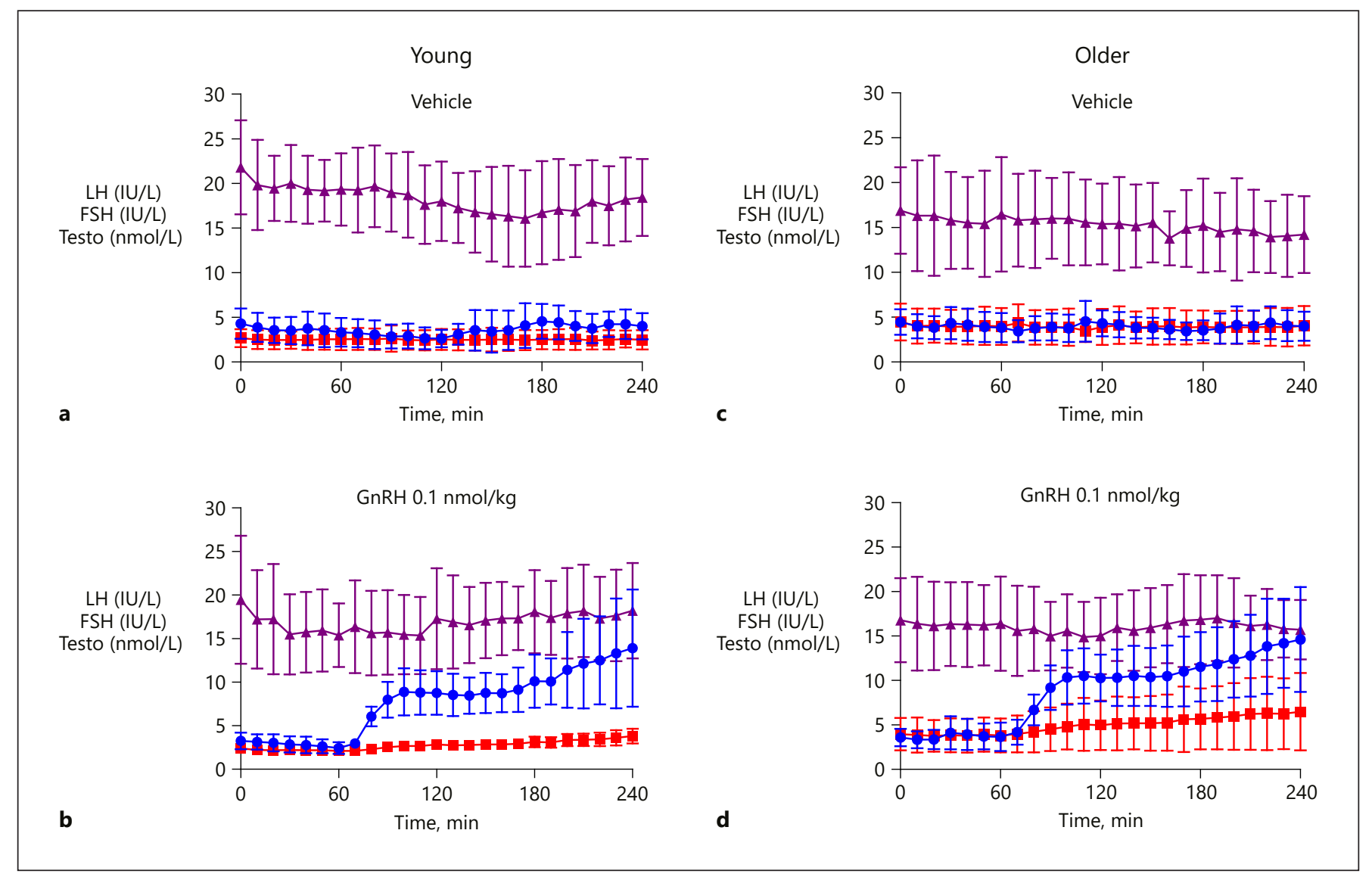

Fig. 2. Reproductive hormone release following $\mathrm{GnRH}$ and vehicle in young and older men. Mean \pm standard deviation of serum hormonal response to $\mathrm{GnRH} 0.1 \mathrm{nmol} / \mathrm{kg} / \mathrm{h}$ and vehicle in young $(n=10)(\mathbf{a}, \mathbf{b})$ and older men ( $n=5$ /group) (c, d). Serum LH (IU/L) is shown in blue, serum FSH (IU/L) in red, and serum testosterone $(\mathrm{nmol} / \mathrm{L})$ in purple. FSH, follicle-stimulating hormone; $\mathrm{GnRH}$, gonadotropin-releasing hormone; $\mathrm{LH}$, luteinising hormone; Testo, testosterone.

sis was performed using multilevel linear regression. Two-level models were used with individual measurements nested within patients. To evaluate how the differences between treatments in terms of changes over time varied between age groups, the analysis included a three-way interaction between time, treatment, and age group. Due to the relatively large number of combinations between pairs of groups, only comparisons with a $p$ value $<0.01$ were considered statistically significant.

\section{Results}

Study 1: Determining the Effects of Kisspeptin-54 and GnRH on Gonadotropin Release in Older Men

Participant characteristics as well as baseline gonadotropin and sex steroid levels are presented in Table 1. Neither serum LH $(p=0.88)$, serum FSH $(p=0.14)$, nor se- rum testosterone $(p=0.13)$ significantly differed at baseline. No participants reported any adverse effects.

$L H$. GnRH and all doses of kisspeptin-54 resulted in a significant increase in LH compared to vehicle $(p<0.001$ for all), with the predominant increase occurring within 40 min of the start of the infusion (Fig. $2 c, d, 3 d-f$ ). LH increase was significantly higher following an equimolar dose of GnRH $(0.1 \mathrm{nmol} / \mathrm{kg} / \mathrm{h})$ (Fig. 2d) than kisspeptin-54 $(0.1 \mathrm{nmol} / \mathrm{kg} / \mathrm{h})(p<0.001)$ (Fig. 3d).

$F S H$. The results suggested a similar pattern to those observed for LH. GnRH and all doses of kisspeptin-54 resulted in a significant increase in FSH release compared to vehicle ( $p<0.001$ for all) (Fig. $2 c, d, 3 d-f$ ). As with LH, there was a significantly higher increase in FSH release in response to $\mathrm{GnRH}(0.1 \mathrm{nmol} / \mathrm{kg} / \mathrm{h})$ (Fig. 2d) compared to kisspeptin-54 (0.1 nmol/kg/h) $(p=0.004)$ (Fig. 3d). 


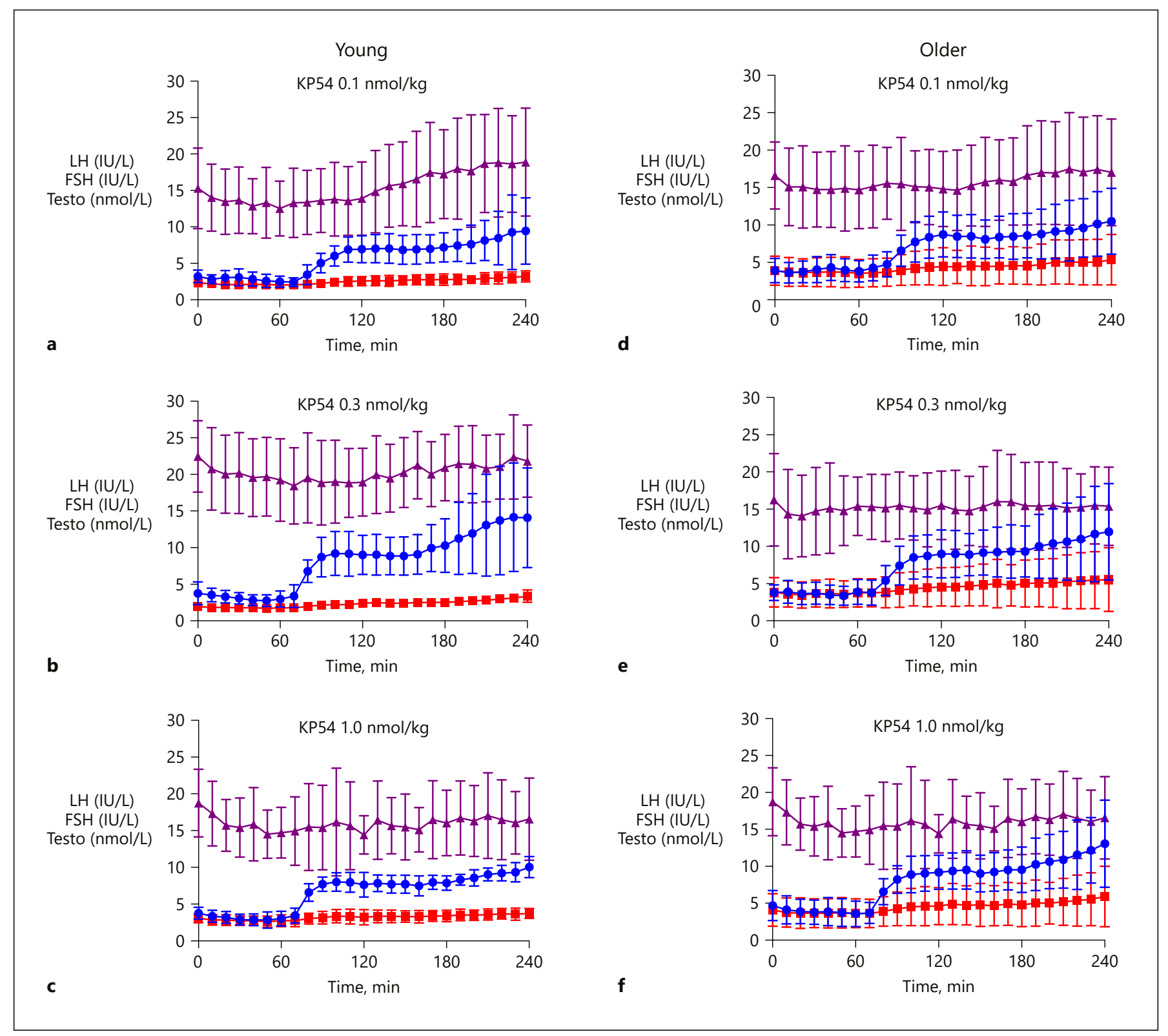

Fig. 3. Reproductive hormone release following kisspeptin-54 in young and older men. Mean \pm standard deviation of serum hormonal response to kisspeptin-54 0.1, 0.3 , and $1 \mathrm{nmol} / \mathrm{kg} / \mathrm{h}$ in young $(n=10)(\mathbf{a}-\mathbf{c})$ and older men ( $n=5$ /group) (d-f). Serum LH (IU/L) is shown in blue, serum FSH (IU/L) in red, and serum testosterone (nmol/L) in purple. FSH, follicle-stimulating hormone; KP54, kisspeptin-54; LH, luteinising hormone; Testo, testosterone.

Testosterone. There was a significant increase in testosterone following kisspeptin-540.1 nmol/kg, kisspeptin-54 $0.3 \mathrm{nmol} / \mathrm{kg}$, and $\mathrm{GnRH}(p<0.01)$ when compared to vehicle. The rise in serum testosterone did not quite reach statistical significance following kisspeptin-54 $1.0 \mathrm{nmol} /$ $\operatorname{kg}(p=0.05)$.
Study 2: Comparison of the Gonadotropin Response to Kisspeptin-54 and GnRH in Older and Young Men

The baseline characteristics of the young men have previously been published (Table 1 ). The mean \pm SEM were: age $28.9 \pm 2.0$ years, BMI $23.6 \pm 0.7, \mathrm{LH} 3.52 \pm$ $0.43 \mathrm{IU} / \mathrm{L}, \mathrm{FSH} 2.50 \pm 0.25 \mathrm{IU} / \mathrm{L}$, and testosterone $20.6 \pm$ $2.0 \mathrm{nmol} / \mathrm{L}$. 
Fig. 4. Change in hormonal values from baseline with intervention in young and older men. The changes in LH (a), FSH (b), and total testosterone (c) from baseline are shown in older and young men who attended for five study visits at least 1 week apart. Significant differences were observed between older and young men for serum LH following kisspeptin-54 1.0 $\mathrm{nmol} / \mathrm{kg} / \mathrm{h}(p=0.003)$, for serum FSH following GnRH ( $p=0.002)$, and for total testosterone following kisspeptin-54 0.1 $\mathrm{nmol} / \mathrm{kg} / \mathrm{h}(p<0.001)$, kisspeptin-54 0.3 $\mathrm{nmol} / \mathrm{kg} / \mathrm{h}(p=0.001)$, and kisspeptin-54 $1.0 \mathrm{nmol} / \mathrm{kg} / \mathrm{h}(p=0.009)$. FSH, folliclestimulating hormone; GnRH, gonadotropin-releasing hormone; KP0.1, infusion of kisspeptin-54 at $0.1 \mathrm{nmol} / \mathrm{kg} / \mathrm{h}$; KP0.3, infusion of kisspeptin-54 at $0.3 \mathrm{nmol} / \mathrm{kg} / \mathrm{h}$; KP1.0, infusion of kisspeptin-54 at 1.0 $\mathrm{nmol} / \mathrm{kg} / \mathrm{h}$; LH, luteinising hormone; $\mathrm{O}$, older men; $\mathrm{Y}$, young men.
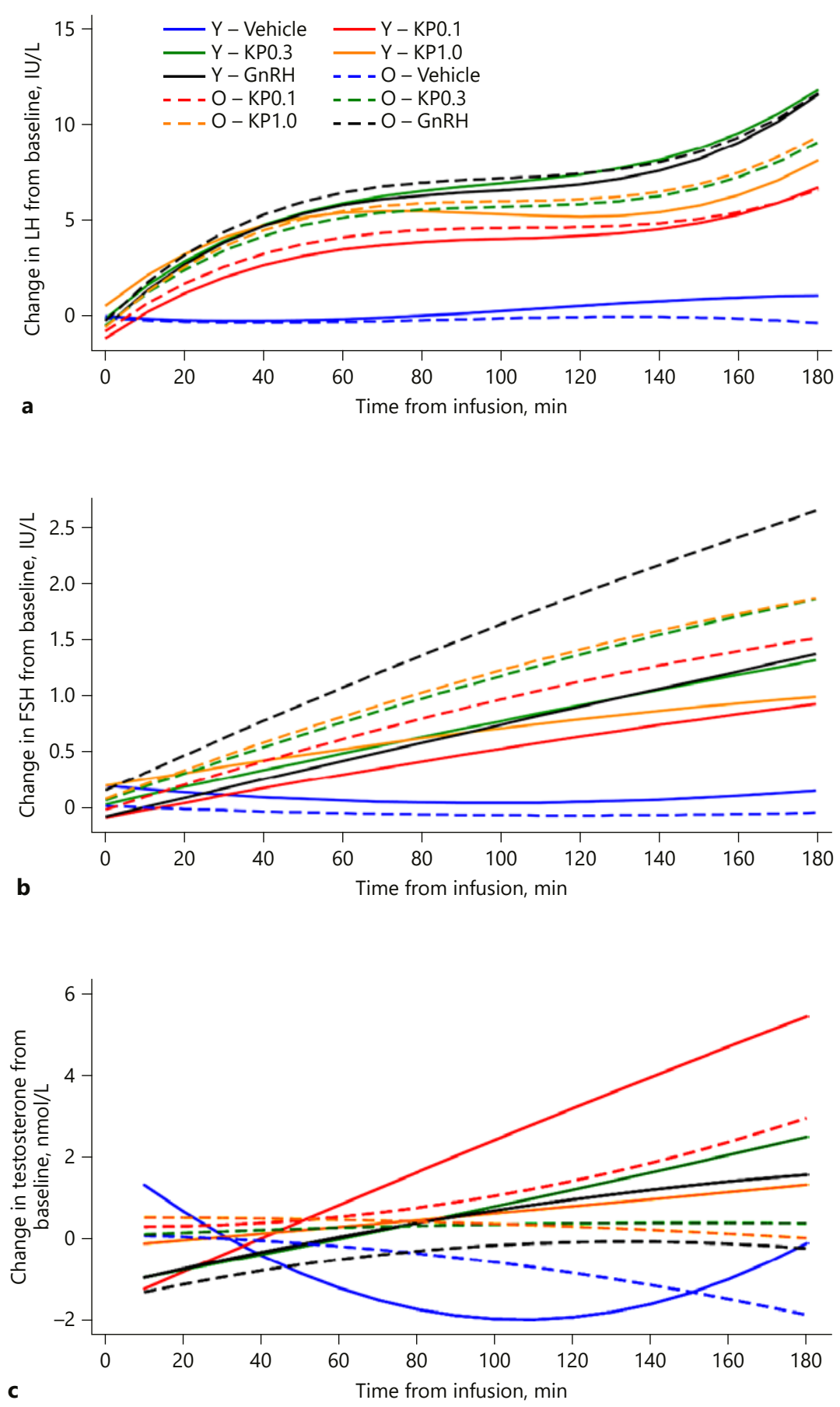

C

ence in $\mathrm{LH}$ response between older and young men following kisspeptin-54 $0.1 \mathrm{nmol} / \mathrm{kg} / \mathrm{h}(p=0.51)$, kisspeptin-54 $0.3 \mathrm{nmol} / \mathrm{kg} / \mathrm{h}(p=0.38)$, or GnRH $(p=0.38)$ over vehicle. However, there was a significantly greater increase in LH over vehicle in older men following kiss- 
peptin-54 $1.0 \mathrm{nmol} / \mathrm{kg} / \mathrm{h}$ when compared to young men ( $p=0.003)$ (Fig. 2, 3, 4a).

FSH. The FSH responses in both older and young men following vehicle, GnRH, and kisspeptin-54 are demonstrated in Figures 2 and 3. The change in FSH from baseline following each intervention in older and younger men is presented in Figure 4b. There was no significant difference in FSH release over vehicle between older and young men following kisspeptin-54 $0.1 \mathrm{nmol} / \mathrm{kg} / \mathrm{h}(p=$ $0.13)$ or kisspeptin-54 $0.3 \mathrm{nmol} / \mathrm{kg} / \mathrm{h}(p=0.13)$. A significantly increased FSH response over vehicle following $\mathrm{GnRH} 0.1 \mathrm{nmol} / \mathrm{kg} / \mathrm{h}(p=0.002)$ and a trend towards significance following kisspeptin-54 $1.0 \mathrm{nmol} / \mathrm{kg} / \mathrm{h}(p=$ $0.04)$ were observed in older men when compared to young men (Fig. 2, 3, 4b).

Testosterone. Despite similar baseline testosterone levels, the increases in testosterone following kisspeptin-54 0.1 $\mathrm{nmol} / \mathrm{kg} / \mathrm{h}(p<0.001)$, kisspeptin-54 $0.3 \mathrm{nmol} / \mathrm{kg} / \mathrm{h}(p=$ $0.001)$, and kisspeptin-54 $1.0 \mathrm{nmol} / \mathrm{kg} / \mathrm{h}(p=0.009)$ were higher in young than older men (Fig. 2, 3, 4c). There was also a trend towards a greater increase in testosterone following GnRH in young compared to older men $(p=0.02)$.

\section{Discussion}

There is an increased frequency of biochemical and clinical hypogonadism with age, which in the absence of other causes is termed late-onset hypogonadism (LOH). Evidence suggests that testicular sensitivity is reduced with age, although there may additionally be defects at the hypothalamus and the pituitary gland. Whilst it is possible to test the testes with hCG or recombinant $\mathrm{LH}$, and the pituitary gland with $\mathrm{GnRH}$, it has hitherto not been possible to directly test the hypothalamus. Therefore, we investigated whether the hypothalamic response to kisspeptin-54 was preserved in older men. In this study of healthy older men without $\mathrm{LOH}$, we observed that the hypothalamic response to kisspeptin-54 and the pituitary response to $\mathrm{GnRH}$ were both at the very least preserved, although the testicular response was attenuated when compared to young men. Of note, BMI in older men was similar to that in young men (Table 1). Thus, we could investigate hypothalamic response to kisspeptin-54 with age in the absence of confounding due to obesity or alterations in sex hormone milieu.

Mulligan et al. [16] suggested a testicular defect in the aetiology of $\mathrm{LOH}$ by demonstrating that there was a failure to increase serum testosterone in older men following 2 weeks of pulsatile GnRH administration. In a ran- domised, placebo-controlled study, they administered intravenous pulses of $\mathrm{GnRH}$ (100 ng/kg intravenously every $90 \mathrm{~min}$ ) to 5 young men (aged 20-34 years) and 5 older men (aged 60-78 years). Whilst older men had more disorderly LH secretion at baseline, LH pulse frequency and amplitude could be normalised with pulsatile $\mathrm{GnRH}$ therapy. Likewise, in a further study by Bergendahl et al. [32] investigating the effect of stressors on gonadotropin secretion, it was noted that in the fed state, older men had lower LH pulse amplitude and LH pulse frequency compared to young men. Taken together, these findings suggest reduced testicular sensitivity, but preserved pituitary sensitivity, with increasing age.

At all doses of kisspeptin-54, gonadotropin response following kisspeptin-54 was at the very least preserved in older men. Strikingly, at the highest dose of kisspeptin-54 tested, the LH response was exaggerated in older men when compared to younger men, although the response to $\mathrm{GnRH}$ was unaltered. This finding would be consistent with increased hypothalamic sensitivity to kisspeptin-54 at GnRH neurones in older men. One could hypothesise that this occurred due to hypothalamic kisspeptin-54 neuronal ageing leading to reduced endogenous kisspeptin-54 secretion in older men and thus increased kisspeptin-54 receptor expression on GnRH neurones, as occurs in other models of HPG axis dysfunction [33]. However, although the serum FSH response also trended towards being increased in older men following the highest dose of kisspeptin-54 $(p=0.04)$, the FSH response was also significantly increased following GnRH in older men. Thus, the FSH response observed following the highest dose of kisspeptin-54 could additionally be explained by increased pituitary sensitivity to GnRH. These findings are consistent with studies demonstrating increased pituitary sensitivity to GnRH in older men [17]. Zwart et al. [17] observed a greater gonadotropin response to $\mathrm{GnRH}$ in older men ( $n=10$, mean age 66 years) when compared to younger men ( $n=9$, mean age 26 years). The discrepancy between the LH and FSH responses to kisspeptin-54 and GnRH could partly be ascribed to differences in baseline serum gonadotropin levels. The absolute rise in serum LH following $\mathrm{GnRH}$ correlates strongly with the rise in serum FSH, whilst higher baseline gonadotropin levels often result in exaggerated responses to $\mathrm{GnRH}$ [19]. Although non-significant, there was a trend towards higher baseline FSH levels in older men (3.7 vs. $2.5 \mathrm{IU} / \mathrm{L}$ ), whereas baseline LH levels ( 3.7 vs. $3.5 \mathrm{IU} / \mathrm{L}$ ) were more similar between the groups, perhaps reflecting a difference in inhibin.

In this study, there was a significantly greater gonadotropin response following equimolar doses of $\mathrm{GnRH}$ 
$(0.1 \mathrm{nmol} / \mathrm{kg} / \mathrm{h})$ than kisspeptin-54 $(0.1 \mathrm{nmol} / \mathrm{kg} / \mathrm{h})$ in older males ( $p \leq 0.004)$, consistent with our previous observations in younger men [29]. The half-life of endogenous GnRH is 2-4 min [34], whilst that of kisspeptin-54 is $27.6 \mathrm{~min}$ [28], making any difference in pharmacokinetics unlikely to account for this observation. However, the greater gonadotropin response following $\mathrm{GnRH}$ is consistent with data suggesting that not all $\mathrm{GnRH}$ neurones express the kisspeptin-54 receptor and that some GnRH neuronal nerve terminals may not be contiguous with pituitary $\mathrm{GnRH}$ receptors $[35,36]$.

Unexpectedly, the rise in serum testosterone was more marked following kisspeptin-54 at a dose of $0.1 \mathrm{nmol} / \mathrm{kg} / \mathrm{h}$ than either GnRH or higher kisspeptin-54 doses. Whilst this could be a chance finding, it was consistent in both young and older groups. Hence, one could speculate that this might indicate a dose-related direct effect of kisspeptin-54 at the testes. Kisspeptin-54 receptors are present in the testes, and kisspeptin- 54 has been observed to significantly increase hCG-stimulated testosterone response in monkeys, consistent with a direct testicular action [37].

In summary, we have assessed the hypothalamic sensitivity to kisspeptin-54 and the pituitary sensitivity to $\mathrm{GnRH}$ in older men without LOH. We observed that the hypothalamic response to kisspeptin-54 is preserved in healthy older men. Thus, further studies evaluating the use of kisspeptin-54 to investigate the hypothalamic contribution to gonadal dysfunction in men with $\mathrm{LOH}$ are now indicated.

\section{Statement of Ethics}

Ethical approval was granted by the Hammersmith, Queen Charlotte's and Chelsea Hospitals Research Ethics Committee, London (registration: 12LO/0507). The study was performed in accordance with the Declaration of Helsinki.

\section{Disclosure Statement}

The authors have no conflicts of interest to declare.

\section{Funding Sources}

The Section of Endocrinology and Investigative Medicine of Hammersmith Hospital is funded by grants from the MRC, BBSRC, and NIHR, an Integrative Mammalian Biology (IMB) Capacity Building Award, and an FP7-HEALTH-2009-241592 EuroCHIP grant, and it is supported by the NIHR Biomedical Research Centre Funding Scheme. The authors are grateful to the NIHR/ Wellcome Trust Imperial Clinical Research Facility for providing infrastructure for this study. The views expressed are those of the authors and not necessarily those of the NHS, the NIHR, or the Department of Health.

A. Abbara is supported by an Imperial College Clinician Researcher Award. S. Narayanaswamy and the department are supported by the NIHR Imperial Biomedical Research Centre Funding Scheme. C. Izzi-Engbeaya is supported by an MRC Clinical Research Training Fellowship. A.N. Comninos is supported by a Wellcome Trust/GlaxoSmithKline Translational Medicine Training Fellowship. S.A. Clarke and W.S. Dhillo are supported by an NIHR Research Professorship.

\section{Author Contributions}

All authors provided contributions to study conception, study design, acquisition of data or analysis and interpretation of data, drafting of the article, critical revision for important intellectual content, and final approval of the version to be published. Here are the most important contributions of each author: A. Abbara, C.N. Jayasena, and W.S. Dhillo designed the study. Data were collected by A. Abbara, S. Narayanaswamy, C. Izzi-Engbeaya, A.N. Comninos, Z. Malik, D. Papadopoulou, A. Clobentz, and Z. Sarang. Analysis was carried out by P. Bassett. S.A. Clarke contributed to the interpretation of results and to the writing and finalising of the manuscript. W.S. Dhillo takes the final responsibility for this article.

\section{References}

1 Harman MS, Metter JE, Tobin JE, Pearson J, Blackman MR: Longitudinal effects of aging on serum total and free testosterone levels in healthy men. J Clin Endocrinol Metab 2001; 86:724-731.

2 Wu FCW, Tajar A, Pye SR, Silman AJ, Finn JD, O'Neill TW, et al: Hypothalamic-pituitary-testicular axis disruptions in older men are differentially linked to age and modifiable risk factors: the European Male Aging Study. J Clin Endocrinol Metab 2008;93:2737-2745.

3 Tajar A, Forti G, O’Neill TW, Lee DM, Silman AJ, Finn JD, et al: Characteristics of secondary, primary, and compensated hypogonad- ism in aging men: evidence from the European Male Ageing Study. J Clin Endocrinol Metab 2010;95:1810-1818.

4 Xia F, Wang N, Han B, Li Q, Chen Y, Zhu C, et al: Hypothalamic-pituitary-gonadal axis in aging men and women: increasing total testosterone in aging men. Neuroendocrinology 2017;104:291-301.

5 Kelsey TW, Li LQ, Mitchell RT, Whelan A, Anderson RA, Wallace WH: A validated agerelated normative model for male total testosterone shows increasing variance but no decline after age 40 years. PLoS One 2014;9: e109346.
6 Wylie K, Froggatt N: Late onset hypogonadism, sexuality and fertility. Hum Fertil 2010; 13:126-133.

7 Glass AR, Vigersky RA: Resensitization of testosterone production in men after human chorionic gonadotropin-induced desensitization. J Clin Endocrinol Metab 1980;51:13951400.

8 Harman S, Tsitouras PD: Reproductive hormones in aging men. I. Measurement of sex steroids, basal luteinizing hormone, and Leydig cell response to human chorionic gonadotropin. J Clin Endocrinol Metab 1980;51:3540.
Hypothalamopituitary Responses in Young and Older Men
Neuroendocrinology 2018;106:401-410 DOI: $10.1159 / 000488452$ 
9 Mulligan T, Iranmanesh A, Veldhuis JD: Pulsatile iv infusion of recombinant human $\mathrm{LH}$ in leuprolide-suppressed men unmasks impoverished Leydig-cell secretory responsiveness to midphysiological LH drive in the aging male. J Clin Endocrinol Metab 2001;86: 5547-5553.

10 Chen H, Hardy MP, Zirkin BR: Age-related decreases in Leydig cell testosterone production are not restored by exposure to $\mathrm{LH}$ in vitro. Endocrinology 2002;143:1637-1642.

11 Grzywacz FW, Chen H, Allegretti J, Zirkin BR: Does age-associated reduced Leydig cell testosterone production in Brown Norway rats result from under-stimulation by luteinizing hormone? J Androl 1998;19:625-630.

12 Baburski AZ, Sokanovic SJ, Bjelic MM, Radovic SM, Andric SA, Kostic TS: Circadian rhythm of the Leydig cells endocrine function is attenuated during aging. Exp Gerontol 2016;73:5-13.

13 Pincus SM, Mulligan T, Iranmanesh A, Gheorghiu S, Godschalk M, Veldhuis JD: Older males secrete luteinizing hormone and testosterone more irregularly, and jointly more asynchronously, than younger males. Proc Natl Acad Sci USA 1996;93:14100-14105.

14 Winters SJ, Troen P: Episodic luteinizing hormone $(\mathrm{LH})$ secretion and the response of $\mathrm{LH}$ and follicle-stimulating hormone to LH-releasing hormone in aged men: evidence for $\mathrm{co}^{-}$ existent primary testicular insufficiency and an impairment in gonadotropin secretion. J Clin Endocrinol Metab 1982;55:560-565.

15 Liu PY, Pincus SM, Takahashi PY, Roebuck PD, Iranmanesh A, Keenan DM, et al: Aging attenuates both the regularity and joint synchrony of LH and testosterone secretion in normal men: analyses via a model of graded GnRH receptor blockade. Am J Physiol Endocrinol Metab 2006;290:E34-E41.

16 Mulligan T, Iranmanesh A, Kerzner R, Demers LW, Veldhuis JD: Two-week pulsatile gonadotropin releasing hormone infusion unmasks dual (hypothalamic and Leydig cell) defects in the healthy aging male gonadotropic axis. Eur J Endocrinol 1999;141:257-266.

17 Zwart A, Urban R, Odell W, Veldhuis J: Contrasts in the gonadotropin-releasing hormone dose-response relationships for luteinizing hormone, follicle-stimulating hormone and alpha-subunit release in young versus older men: appraisal with high-specificity immunoradiometric assay and deconvolution analysis. Eur J Endocrinol 1996;135:399-406.
18 Veldhuis JD, Veldhuis NJD, Keenan DM, Iranmanesh A: Age diminishes the testicular steroidogenic response to repeated intravenous pulses of recombinant human LH during acute $\mathrm{GnRH}$-receptor blockade in healthy men. Am J Physiol Endocrinol Metab 2005; 288:E775-E781.

19 Bang AK, Nordkap L, Almstrup K, Priskorn L, Petersen JH, Rajpert-De Meyts E, et al: Dynamic GnRH and hCG testing: establishment of new diagnostic reference levels. Eur J Endocrinol 2017;176:379-391.

20 Bonavera J, Swerdioff R, Sinha Hakim A, Lue Y, Wang C: Aging results in attenuated gonadotropin releasing hormone-luteinizing hormone axis responsiveness to glutamate receptor agonist N-methyl-D-aspartate. J Neuroendocrinol 1998;10:93-99.

21 Coquelin A, Desjardins C: Luteinizing hormone and testosterone secretion in young and old male mice. Am J Physiol 1982; 243:E257-E263.

22 Gruenewald DA, Naai MA, Marck BT, Matsumoto AM: Age-related decrease in hypothalamic gonadotropin-releasing hormone $(\mathrm{GnRH})$ gene expression, but not pituitary responsiveness to $\mathrm{GnRH}$, in the male Brown Norway rat. J Androl 2000;21:72-84.

23 Jarjour L, Handelsman D, Swerdloff R: Effects of aging on the in vitro release of gonadotropin-releasing hormone. Endocrinology 1986; 119:1113-1117.

24 Takahashi PY, Liu PY, Roebuck PD, Iranmanesh A, Veldhuis JD: Graded inhibition of pulsatile luteinizing hormone secretion by a selective gonadotropin-releasing hormone $(\mathrm{GnRH})$-receptor antagonist in healthy men: evidence that age attenuates hypothalamic GnRH outflow. J Clin Endocrinol Metab 2005;90:2768-2774.

25 de Roux N, Genin E, Carel JC, Matsuda F, Chaussain JL, Milgrom E: Hypogonadotropic hypogonadism due to loss of function of the KiSS1-derived peptide receptor GPR54. Proc Natl Acad Sci USA 2003;100:10972-10976.

26 Seminara SB, Messager S, Chatzidaki EE, Thresher RR, Acierno JS, Shagoury JK, et al: The GPR54 gene as a regulator of puberty. N Engl J Med 2003;349:1614-1627.

27 Skorupskaite K, George JT, Anderson RA: The kisspeptin-GnRH pathway in human reproductive health and disease. Hum Reprod Update 2014;20:485-500.
28 Dhillo WS, Chaudhri OB, Patterson M, Thompson EL, Murphy KG, Badman MK, et al: Kisspeptin-54 stimulates the hypothalamic-pituitary gonadal axis in human males. J Clin Endocrinol Metab 2005;90:6609-6615.

29 Jayasena CN, Abbara A, Narayanaswamy S, Comninos AN, Ratnasabapathy R, Bassett $\mathrm{P}$, et al: Direct comparison of the effects of intravenous kisspeptin-10, kisspeptin-54 and $\mathrm{GnRH}$ on gonadotrophin secretion in healthy men. Hum Reprod 2015;30:1934-1941.

30 Edwards CMB, Todd JF, Mahmoudi M, Wang Z, Wang RM, Ghatei MA, et al: Glucagon-like peptide 1 has a physiological role in the control of postprandial glucose in humans: studies with the antagonist exendin 9-39. Diabetes 1999;48:86-93.

31 Kraegen EW, Lazarus L, Meler H, Campbell L, Chia YO: Carrier solutions for low-level intravenous insulin infusion. Br Med J 1975;3: 464-466.

32 Bergendahl M, Aloi JA, Iranmanesh A, Mulligan TM, Veldhuis JD: Fasting suppresses pulsatile luteinizing hormone (LH) secretion and enhances orderliness of LH release in young but not older men. J Clin Endocrinol Metab 1998;83:1967-1975.

33 Castellano JM, Navarro VM, FernándezFernández R, Nogueiras R, Tovar S, Roa J, et al: Changes in hypothalamic KiSS-1 system and restoration of pubertal activation of the reproductive axis by kisspeptin in undernutrition. Endocrinology 2005;146:3917-3925.

34 Kumar P, Sharma A: Gonadotropin-releasing hormone analogs: understanding advantages and limitations. J Hum Reprod Sci 2014;7: 170-174.

35 Irwig MS, Fraley GS, Smith JT, Acohido BV, Popa SM, Cunningham MJ, et al: Kisspeptin activation of gonadotropin releasing hormone neurons and regulation of KiSS-1 mRNA in the male rat. Neuroendocrinology 2004;80:264-272.

36 Han SK, Gottsch ML, Lee KJ, Pope SM, Smith JT, Jakawich SK, et al: Activation of gonadotropin-releasing hormone neurons by kisspeptin as a neuroendocrine switch for the onset of puberty. J Neurosci 2005;25:1134911356.

37 Irfan S, Ehmcke J, Wahab F, Shahab M, Schlatt S: Intratesticular action of kisspeptin in rhesus monkey (Macaca mulatta). Andrologia 2014;46:610-617. 